\title{
Offentlig hjelp til etterlatte i norske kommuner
}

\author{
Ved Kari Dyregrov
}

I 1998 var det 24 kvinner og 75 menn under 30 år som tok sitt liv (egen statistikk basert på opplysninger fra Politiets straffesaksregister og folkeregisteret). Selv om det ikke foreligger statistikk over antallet etterlatte etter selumord, er det i Norge hvert år flere tusen kriserammede mennesker som følge av selvmord. I denne artikkelen skal vi se naermere på hva slags oppfølging etterlatte ved unge menneskers selumord tilbys i de ulike kommunene i Norge.

\section{Etterlatte sliter}

Det er dokumentert at mange etterlatte sliter med store personlige problemer (M cIntosh 1990; M üller 1992). En rekke undersøkel ser har vist at plutselige dødsfall innebærer større helsemessige konsekvenser for etterlatte enn tilfellet er etter forventede dødsfall (Parkes\& W eiss 1983; Figley 1989). For pårørende innebærer dette at de ikke bare opplever sorg som følge av tap av et nært familiemedlem, men også et traume. $M$ ens kjernen i sorgen er savn og lengsel, påfører måten det skjer på spesifikke, ofte langvarige ettervirkninger. Kroppslig uro og aktivering er som oftest høyere enn etter forventede dødsfall, og påtrengende minner/fantasier om det som hendte, samt at man unngår det som minner om dødsfallet, er vanlige følger (Dyregrov 1993). Etter selvmord sliter mange i tillegg med skyldfølelse, skam og sinne. $M$ ange vil kunne fă sosiale vansker i form av selvpålagt isolasjon, eller gradvis reduksjon i sosial omgang ved at andre viker unna kontakt. Fagfolk som har arbei det med etterlatte etter selvmord, har etterlyst systematisk hjel p og bistand, spesielt til barn (Svenberg 1987; Müller 1992).

\section{Presentasjon av prosjektet}

Prosjektet "O msorg for etterlatte etter selvmord" er ett av to komparative forskningsprosjekter. D et andre prosjektet har fokus på omsorg for etterlatte etter krybbedød og barneulykker. $H$ vert av prosjektene består igjen av to delstudier. I den første delstudien - Kommunestudien (Dyregrov, N ordanger \& Dyregrov 1998) ønsket man å kartlegge innhold og organisering av omsorgen fra det offentlige hjelpeapparatet. En landsomfattende spørreskjemaundersøkelse ble besvart av 321 av 481 norske kommuner/bydeler. Fra besvarelsene var det 156 kommuner som mente de ful gte opp etterlatte etter selvmord med spesifikke tilbud (selvmordsutvalget), og 110 kommuner som definerte seg å ha oppfølgingstil bud etter brå død generelt (brå dødutvalget). Resultatene fra selvmordsutvalget presenteresi denne artikkel en. Innsamlingen av spørreskjemaene pågikk fra februar 1998 til medio august 1998. I den andre og pågåen de del studien (Etterlattestudien) undersøkes etterlattes situasjon, deres behov for hjelp, samt deres opplevelse av omsorgstilbudet etter selvmord. Resultatene vil foreligge i en rapport, medio år 2000. H ensikten med prosjektet er å utarbeide forslag til tiltak og/eller retningslinjer for omsorg for etterlatte.

\section{Hovedfunn fra Kommunestudien}

Det er store forskjeller i omsorgstilbudet i norske kommuner, fra liten hjelp til planmessig oppfølging med spesial rettede tiltak. Variasjonene i tilbudet er særlig knyttet til om kommunene har kriseteam, fast koordinator, skriftlige rutiner for hjel petiltak og skriftlige rutiner mellom første- og annenlinjetjenesten.
Forekomst av en eller flere av disse organiserende strukturene sammen med større "oversiktlighet" i små kommuner bidrar til at omsorgstilbudet for etterlatte etter selvmord synes å være best i mindre og mellomstore kommuner med klare ansvarsforhold. Det er nokså tilfeldige strategier for kontaktetablering, oppfølgingstiden varierer, hjelpen til barn synes mangelfull, og norske kommuner har (ikke nødvendigvis tar) generelt kontakt med etterlatte relativt raskt etter dødsfall let. Dette skyldes for en stor del at andre familiemedlemmer og venner eller den etterlatte selv tar kontakt og ikke bare det offentlige.

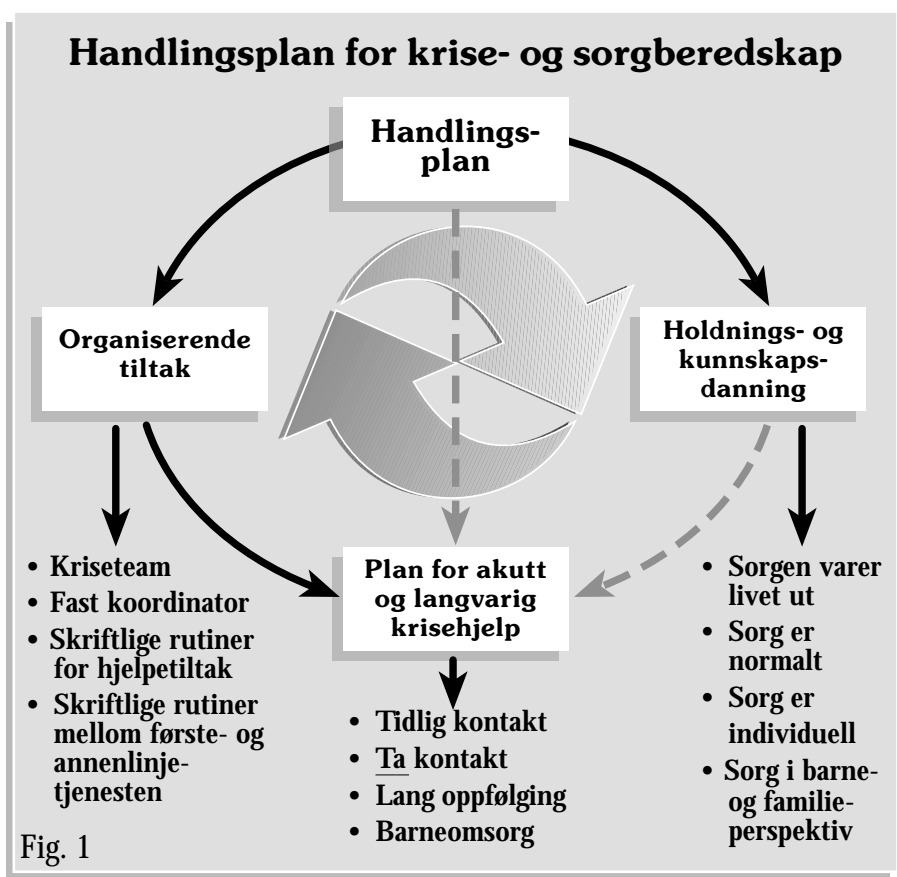

Tilfeldig kontaktetablering og oppfølgingstilbud

Sjansen for at etterlatte etter selvmord ikke orker å ta den første kontakten med hjelpeapparatet, er særlig stor den første tiden. M ed kunnskap om den hjel peløshets- og sjokktilstand etterlatte befinner seg i etter et selvmord og den grad av sosial tilbaketrekning som ofte følger, kan tidspunkt og måten det etableres kontakt på være et kritisk punkt i forhold til om etterlatte får den hjelp de trenger. Sorglitteraturen viser at hjel pen uansett må komme hurtig og komme til den kriserammede (W orden 1983; Figley 1989; Dyregrov \& Dyregrov 1999). I forhold til denne kunnskapen peker resul tatene på et avgjørende hinder for et godt omsorgstilbud i kommunene. $\mathrm{H}$ jelpen, enten den er psykologisk, medisinsk eller praktisk/økonomisk, må være oppsøkende og respektful lt "overtalende", og man må kontakte de etterlatte igjen dersom man blir avvist første gang. I en studie av etterlatte 12-15 år etter tap av barn i krybbedød oppfordrer foreldre hjel peapparatet nettopp til "å være en god selger" (Dyregrov \& Dyregrov 1999). 
$\AA$ rsaken til at det bare er en tredjedel av kommunene i selvmordsutval get (og bare $17 \%$ av brá død-utval get) som fast oppsøker etterlatte for å tilby hjelp, henger sannsynligvis sammen med flere forhold. Kommunene peker selv på at tids- og kapasitetshensyn fører til at man i en del kommuner forholder seg til akutte oppgaver som "må" tas. De har ikke ressurser eller overskudd til à tenke forebyggende og tilby hjelp før de hjel petrengende henvender seg til dem. I andre kommuner lider man under manglende organisering og planer for krisearbeid, eller eksisterende planer er ikke detaljerte og presise nok. M angl ende kompetanse og usikkerhet når det gjelder hvordan hjelpeapparatet skal forholde seg til etterlatte etter selvmord, er andre grunner.

\section{Kort oppfølgingstid}

Selv om det vil være individuell variasjon og kjønnsforskjeller med hensyn til reaksjonenes intensitet, vet man at sorg- og traumereaksjoner preger etterlattes liv i årevis, og mange vil trenge hjelp utenfra

(Parkes 1983; Svenberg 1987). A t bare en tredjedel av kommuner som mener de har spesifikke tilbud ved

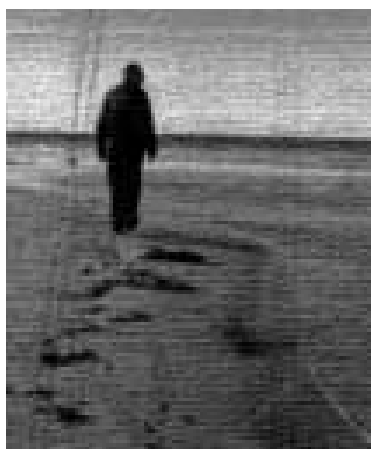
selvmord følger opp etterlatte inntil et år, bekrefter tendensen fra tidligere studier om at etterlatte tilbys mest støtte de første månedene, for så å bli overlatt mer til seg selv når de virkelig skal ta fatt på sorgarbeidet. Dette kan ofte knyttes til at omgivelsene, hjel peapparatet inkludert, undervurderer sorg og traumers intensitet og varighet. A t så mange kommuner velger å krysse av på kategorien "varierer", peker også mot de store individuelle forskjellene som nødvendigvis vil være til stede ut fra ulike behov for oppfølging over tid. Således kan man håpe at det er langt flere kommuner som har kontakt med etterlatte når årsdagen for dødsfallet passeres, enn det resultatene antyder.

\section{Mangelfull omsorg for barn}

$\mathrm{N}$ år man vet hvor mye små barn oppfatter av død og sorg og man kjenner til deres behov for å kunne sørge (M üller 1992; Dyregrov 1989), er det ikke tilfredsstillende at halvparten av kommunene ikke nevner tiltak for barn som opplever at det skjer selvmord i nær familie. M ens voksne f.eks. tilbys støttesamtaler fra ulike faggrupper i 3/4 av kommunene, er det bare i $20 \%$ av kommunene at barna får tilbud om slike samtaler. Dette tyder på at barn ikke tas på al vor som etterlatte, noe som også har vært hevdet og etterlyst i litteraturen. I kommunenes beskrivelser av områder for fremtidig satsing er omsorg for barn også påfallende sjelden nevnt. I vedlegg fra 29 kommuner som har skriftlige rutiner for omsorgstilbud, er imidlertid barn til en viss grad omtalt og ivaretatt. Forklaringene på en tilsynelatende svikten de omsorg for barn kan være flere.

U sikkerhet omkring forståelse av barns sorg har vært utbredt, blant annet fordi barn ikke sørger på samme måte som voksne. $M$ anglende hjel p til barn kan således skyldes at man ikke føler seg kompetent til å kommunisere med barn om sorg, og man setter sin lit til at barna kan hjel pes via foreldrene. A ndre forklaringer kan være manglende fokus på eller vilje til å prioritere omsorg for barn. A t samtaler med helsesøster og til rettelegging i skole og barnehage er hyppigst nevnte hjel petiltak for barn, avspeiler at dette er arenaer hvor barn ferdes, og at skolen har

tatt et økende ansvar i forhold til barns psykiske funksjon og trivsel.

\section{Kommunen er tidlig i kontakt}

$\mathrm{H}$ alvparten av kommunene oppgir at noen i kommunen er i kontakt med de etterlatte allerede første dag, og $74 \%$ angir at kontakt er etablert innen tre dager. Som oftest er det prest, lege eller politi som gir dødsbudskap, medisinsk førstehjelp eller politiopplysninger. 0 fte avsluttes kontakten etter dette. Fordi hjel peapparatet i kommunene rutinemessig har kontakt med så mange etterlatte, ligger det her et potensiale for videre oppfølging.

\section{Handlingsplan for krise- og sorgberedskap}

På bakgrunn av omtalte hovedfunn anbefales en overordnet handlingsplan for krise- og sorgberedskap i alle kommuner (se fig.1). Planen bør til passes den enkelte kommunes demografi og geografi, og inneholde en struktur for organisering samt detaljerte planer for iverksetting og gjennomføring av omsorgstilbudet. $\varnothing$ kt kunnskap om sorg- og krisearbeid er viktig for forståel sen av etterlattes reaksjoner etter selvmordet. Det er behov for "en utstrakt hånd" fra omsorgsapparatet, en hånd som kanskje må være der i lengre tid. I tillegg bør omsorgsapparatet ha et overordnet ansvar for å stimulere til å bygge omsorg inn i den sosiale strukturen, basert på mellommenneskelige forhold og lokale betingelser i den enkelte kommune.

\section{Avslutning}

Ettersom det bare er resultatene fra Kommunestudien som er presentert her, er ikke den viktige og gode støtten fra sosialt nettverk og frivillige organisasjoner beskrevet. $\mathrm{H}$ vordan etterlatte opplever slik hjelp, blir beskrevet i rapporten "Etterlattestudien", som ferdigstilles juli 2000.

\section{Litteratur}

Dyregrov A . Sorg hos barn. En håndbok for voksne. Bergen: Sigma, 1989.

Dyregrov A . Katastrofepsykologi. O slo: A d N otam G yldendal, 1993.

Dyregrov A , D yregrov K. Long-term impact og sudden infant death: a 12- to 15-year follow-up. Death Studies, 23: 635-661, 1999.

Dyregrov $K, N$ ordanger $D$, Dyregrov A. O msorg for etterlatte etter selvmord. Kommunestudien. Bergen: Senter for K risepsykologi, 1998.

Figl ey C R. H elping traumatized families. San Francisco: Jossey-Bass, 1989. $M$ clntosh JI. Suicide and its aftermath. Survivor family relationship: literature review. $\mathrm{N}$ ew York: W W. $\mathrm{N}$ orton \& C 0, 1990.

M üller $O$. Etterlatte etter selvmord: reaksjoner og behandlingsbehov. Tidsskrift for N orsk Psykologforening 1992; 29: 189-99.

Parkes CM , W eiss RS. R ecovery from bereavement. $N$ ew York: Basic Books, 1983.

Sven berg G. Etterlatte: behov for hjelp og omsorg til etterlatte etter dødsfall. Rapport. 0 slo:
$\mathrm{N}$ asjonalforeningen for Fol kehelsen, 1987.

W orden WJ. G rief counselling and grief therapy. London: Tavistock, 1983

En mer detaljert presentasjon av Kommunestudien stod i Tidsskrift for Den norske lægeforening 1999; 119 (27): 4010-15.

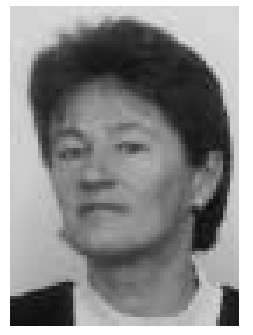

Kari D yregrov er sosiolog og arbeider som forsker ved Senter for krisepsykologi i Bergen. H un har drevet prosjektet "O msorg ved brå, uventet død" som videreføres i et treårig dr. gradsarbeid fra 1. juli 2000. Forskningen tar sikte på økt hel hetsforståel se av problemfel tet og å bidra til an befalinger for å komplettere sorgbistandsapparatet for etterlatte, spesi elt etter selvmord. 